\title{
Regional University Marketing in Under-developed Regions'
}

\begin{abstract}
Specific approaches, in the field of the University marketing, are discussed with the higher intensity last decades. But the Universities established in underdeveloped regions have special position, function, possibilities, and specific needed activities. There are also many reasons for applying modified strategies and marketing tools in Slovak higher educational market. The study deals with main and dominant approaches in this area of managing of educational institutions in Slovak environment but the study also presents the results of the research. The sample of the research was selected from students of the Faculty of Management, University of Prešov, Slovak Republic. There was marketing product policy designed and mainly communications policy and image mainly analysed there. There are offered some suggestions for universities in the final part of the study.
\end{abstract}

\section{Introduction}

Marketing was formerly developed for companies with an aim to commercialise their productions. Marketing went from its beginning through some phases of development and it meets an integrating role at present because it joins

${ }^{1}$ This article is published as one of outputs by solving the research grant VEGA 1/4638/07: "Výskum determinantov a aktivizujúcich prvkov akcelerácie regionálneho rozvoja a návrh znalostného modelu vedúceho $\mathrm{k}$ zvýšeniu konkurenčnosti regiónu s podporou špecifického marketingového inštrumentária" " $R e$ search of the determinants and of the acceleration of regional development activating elements and a proposal of knowledge model leading to the increase of regional competitiveness with the support of specific marketing instrumentarium"). 
many, formerly separated functions of companies. It is accounted as a business philosophy, the way of a company management with a dominant orientation for market.

In spite of the fact, that the marketing was formerly meant only for profitable companies, however, its principles penetrate into totally different fields of the life at present. Non-profitable companies had to react to growing pressure of competitive market. Marketing usage became topical. It leads to fulfil a role and aims of non-profitable organizations. For some of them it could be a way to survive in business. Marketing is joined with approaching and upgrading of service and many of them are joined with the non-profitable sector - education, health care, culture, social services, etc. Effective using of usually limited financial sources that non-profitable organizations have. Not even non-profitable organizations can offer products that nobody is interested in, and marketing can arrange the framework and tools for identification and segmentation of market; surveying demands and needs to create the basics of marketing mix prepared this way. Marketing framework unifies efforts of non-profitable organization to approach the highest possible value and profit for the organization and their target groups by the elements of the marketing mix.

\section{Main Required Activities from Regional Universities}

As the significant under-developed regions we can analyse some particular Slovak regions, mainly regions in the area of Eastern Slovakia (for example Prešov region). The regional universities are natural centres of education of every under-developed region.

But some general problems of the public schools are more manifesting in the schools in poor regions (under-developed regions). One of the dominating common problems of public schools in Slovakia is lack of finance. Because of lack of finance, barriers arise that restrict, even exclude a possibility of standing the competitive educational market and it even threatens the fulfilling aim and mission of the universities. The discussion about using of differential school fees in state universities is held for a long time. Positives of school fees are emphasized (social justification for university study, accessibility of sources, responsibility of citizens for solution of existence problems, aspect of motivation, regulation of demand, etc.) and negatives as well (decreasing number of applicants for study, social sub-sequences, loose of talents, etc.). The price of the school fee would determine the price of products of university educational programmes.

We can state, carrying present legal conditions over, restrictions of sources from state budget, as well as other limit factors, this problem will not be solved in a short time. Schools, including Slovak public universities, should orientate how to attract external sources. Other possibilities are some fees (registration fee, school fee for some study programmes, entrance exam fee) and profit from some other educational activities that are not taxed in Slovakia. 
Marketing product of universities is the educational programme and other services connecting with it - complex offer of the university. Also public university should regularly perform market analysis - evaluate satisfaction of present students and demands of candidates, but on the other hand to watch a demand side of labour market, social needs, watch the research development and new disciplines as well. The result of analysis should be modification of study programmes according to real needs.

Slovak Republic joining of the European Union brought for some Slovak universities a problem of compatibility - therefore it is needed to approach the compatibility of fields of study in the Slovak universities with fields of study in the EU universities. That is also an important factor of the university attractiveness. One possibility is setting of credit system up for the university or also the European system of credits transfer (ECTS - European Credit Transfer System) not only for specific fields of study. This is the way of cooperation among Slovak universities and partner foreign schools. The priority and source of the attractiveness of the university is without any doubt also foreign cooperation; using of credit system or ECTS the students and teachers mobility becomes easier and accepting of foreign study in domestic school would be easier.

There is very well known the model "Four P's and Q" in the marketing of services (Chaston, 1990). The tool "Q" means "quality". The quality evaluation in the universities is one the most discussed topics. Most of Slovak universities engage in the problem; some projects run (in the framework of the Tempus programme) that deal with quality evaluation and setting and using of system of quality in universities. It is needed to specify common indicators to be able to judge and compare quality of universities - internally and externally.

The marketing product has to be accessible at most to a holder of demand, a customer, i. e. to a student. Education can be purveyed in own rooms or the school can obliged to a customer, for example to a company, which ordered a lecture for its employees and give a lecture into the company. From the point of view of logistics, it could be offered good situated consultation centres, etc.

From the educational marketing point of view the new forms of study appear in Slovakia at present - distant study, using of new communicative and information technologies - for example, internet using and variety of the applied software programmes. It was said a lot about the whole-life study or for example about universities of the third age. The PU should watch the trends and successively put them into fields of study, where these forms of study could be used.

In the next part of the study there is offered the more detailed plan of marketing communications of the regional university, including setting of marketing and communication aims of the university and a proposal of a creative strategy. 


\section{Setting Up of Marketing and Communication System}

- The analysis of the regional labour market and its development.

- The analysis of the structure of the educational needs, demand in the educational market.

- Increasing of frequency and quality analyses making of a degree of satisfaction of rational student needs and his/her total satisfaction with his/her institution.

- Increasing of the offer attractiveness of the university for highest quality students of secondary schools from the population years as candidates of study of a certain college and university.

- Successive transformation of the higher educational institution into high degree of sensitivity, into so-called "high sensitive organization of services".

- To upgrade the level of reactions of the university institution for imperfections and problems found in satisfaction analysis.

- Increasing interest and high attractiveness for high quality researchers and pedagogical personalities in the institution.

- Increasing of the institution attractiveness as a thoroughgoing employer.

- Increasing of internal communication in the framework of the university.

- More out-of-budget money, including grants.

- Optimisation of fields of study structure and specializations.

- Quality increasing of all university activities.

- Goodwill increasing and prestige of the university comparing nowadays state.

- Attitude change of the students, pedagogical and non-pedagogical employees of the university concerning university matters.

- Employee identification with the university aims.

- Creating of good cooperation climate of collaboration with state and municipal authorities.

- Improving of atmosphere and working conditions in the university by setting non-problem funding of the university (from budget and out-of-budget sources).

- Change of top-candidates-perception of the university - from the position of substitutive solution to the position of their first choice - by candidates, parents of students, secondary school teachers.

- Strengthening and increasing of market position of the university in our region comparing to other public schools or newly established universities.

- Realizing of investment importance to universities (former graduates, companies, organizations, funds, foreign funds, etc). 


\subsection{Creative Strategy}

Creative strategy for communication aim acquirement will vary according to target publics. Target publics are various important groups of the region, also regional stakeholders, and therefore they need different approach to communication.

A) Target publics:

- Employees of the university and present students.

- Candidates, their parents and secondary schools.

- Unemployed groups in the region

- State and municipal authorities.

- Economical sphere, sponsors, graduates, foundations and foreign funds.

B) Promise:

- Increasing of life quality by putting personal and professional aims into practice.

C) Promise support:

- Arranging of excellent work (for employees) and study (for present students) conditions; pleasant milieu; being proud of the institution; good reputation of the university can give better acquitting oneself well.

- Acquisition of good education is inestimable value; better possibility of acquitting oneself; higher society rank; possibilities of whole-life education, etc.

- Good society climate, discordless cooperation; cooperation in professional matters and town (region, state) has profit from the university success, its rank, image, market position.

- High qualified experienced labour force; good reputation of a company, because cooperation with universities is a prestige; using of foreign contacts of a university; cooperation in fields of science and research.

D) Putting into practice

Intention:

- To get the aims of target groups' attention to the institution.

- To get the offer of the institution in accord to individual interests of the target groups.

\subsection{Forms of Communication}

The most important communication activities should be public relations (PR). Prerequisite to get a considerable positive effect is not only a good college and university presentation, which can cause a satisfaction of students and other target groups. It must be taken maximum pains to know the most general circle of people about the successes of the university.

Other forms of marketing communication, for example an advertisement and sales promotion, etc., are in the case of public university on the next positions and priorities of the marketing communication. 
Among the most important sources of college attractiveness and at the same time a gravitational force affecting to the best candidates of study (as well as quality job candidates) are especially:

- Highly attractive study programmes together with other elements of complex university offer.

- Research and pedagogical personalities working in the academic ground.

- Study and working conditions offered by a university.

- International connections and a degree of compatibility with foreign and other domestic institutions.

In the field of public relations: press articles - articles publishing with information supporting a positive image of the university; articles about the success of the university - its graduates, educators, students, joining of the university into successful projects, competitions, any news about the university, variety changes, etc. Articles about the university should be published minimum once in a month throughout a year and any other important occasion and event or situation, as it is mentioned above (media: radio, newspaper, state and regional magazines and professional magazines).

In the field of public relations: press conferences - organized in cases of special or unusual events.

In the field of public relations: preparation of informative materials - preparation of variety of materials according to the target groups. They could be used for presentations of the school in variety of events; conferences and they should be in more foreign languages. Special materials can be sent by mail printed or in electronic form to potential sponsors or students. Current, but not used, is publishing of almanacs (information about students, teachers, their photographs), something like "Frequent questions" (FAQ - Frequently Asked Questions).

In the field of public relations - "Open Door Days" - to introduce the school once in a year, with the access to all rooms, with accompanying events (the term could be repeated regularly, the most suitable months: October - November, one of the aims should be a building of interest of potential candidates and sponsors).

VIP Club. - interest of people creating public opinion - positive for the university, support source of good reputation. The members can be main sponsors, contributors and successful graduates of the PU.

Marketing activities in the field of „People“:

- Allumni club of the university and of its faculties.

- Organizing of seminars, conferences and meeting at variety of occasions.

- Fairs participation, exhibitions in the field of education and pedagogy.

- Person-to-Person - personal efforts of employees, students, etc.

The visualization is also very important in the university communications:

- Awareness stimulation - generally present and use LOGO of the university anywhere (annexe).

University shop - using of LOGO - pens, cloths, T-shirts, caps, etc.

The school presentation could be through videocassettes, publications, calendars, postcards, etc. 


\section{University Students' Research from the Point of View of Marketing Conception of the University}

In the beginning of March 2006 a research was made in the University Prešov (PU), Slovak Republic. Its aim was to determine how the students of the Faculty of Management of PU in Prešov (FM PU) feel the university, where they were studying. The main aim of the research was to achieve input information for judgement, if and what way the board of FM PU, according to the opinion of students of full-time and extramural study, use marketing for college management.

A sample consists from 350 students of FM PU: 200 of students of full-time study (57\%) and 150 students of extramural study (43\%).

Students got a questionnaire to fulfil it by two ways: through teachers in study groups to be asked students from different forms and different forms of study; in other case they were chosen by chance that lived in the boarding school of PU but they had to fulfil a condition they were students of FM PU.

Figure No 1. Research of chosen factors of satisfaction with the institution and its image

\begin{tabular}{|l|c|c|c|c|}
\hline & $\begin{array}{c}\text { Full-time } \\
\text { students }\end{array}$ & $\begin{array}{c}\text { Extra mural } \\
\text { study students }\end{array}$ & t-value & P (importance) \\
\hline Image of faculty & 2,315000 & 2,160000 & 2,16200 & 0,031299 \\
\hline Education quality & 2,330000 & 2,187919 & 1,91583 & 0,056208 \\
\hline Social programmes & 2,821990 & 2,746269 & 1,00180 & 0,317191 \\
\hline Boarding & 3,359788 & 2,783333 & 5,01350 & 0,000001 \\
\hline Dinners & 3,291892 & 2,718182 & 4,51393 & 0,000009 \\
\hline Accommodation & 2,554913 & 2,676471 & $-0,96311$ & 0,336344 \\
\hline Hall of residence & 2,589595 & 2,708738 & $-0,99997$ & 0,318209 \\
\hline Furnishing of facilities & 2,887755 & 2,861538 & 0,27098 & 0,786582 \\
\hline Cultural events & 2,711340 & 2,857143 & $-1,39525$ & 0,163915 \\
\hline Study literature & 2,395000 & 2,889655 & $-4,10805$ & 0,000050 \\
\hline Publishing activity & 2,918367 & 2,897810 & 0,21990 & 0,826087 \\
\hline Computing technique approach & 2,944444 & 2,893617 & 0,41829 & 0,676005 \\
\hline Copying & 2,944444 & 2,776224 & 1,44547 & 0,149249 \\
\hline Study & 3,120603 & 3,075342 & 0,47958 & 0,631833 \\
\hline Length of semester & 3,517588 & 3,263514 & 2,30297 & 0,021875 \\
\hline Way of testing & 3,422111 & 3,208054 & 1,91827 & 0,055900 \\
\hline Way of teaching & 2,341837 & 3,000000 & $-5,06897$ & 0,000001 \\
\hline Scientific and research aims & 2,664921 & 2,769841 & $-0,92619$ & 0,355056 \\
\hline Practice & 3,422111 & 3,147651 & 2,61281 & 0,009372 \\
\hline Logical order of subjects & 3,155779 & 3,204082 & $-0,47398$ & 0,635815 \\
\hline Preliminary evaluation & 3,187817 & 2,978723 & 2,14254 & 0,032869 \\
\hline
\end{tabular}


Statistically important difference between the students of full-time and extramural study was found in the items of: faculty image, boarding, dinners, study literature, length of semester, logical order of subjects, practice, preliminary evaluation.

In the item of faculty image, both groups positively evaluate this indicator, however the rate of positivity is higher at extramural students $(2,16)$ than at students of full-time study $(2,32)$. This state was caused, I think, because extramural students are mostly employed people coming to the faculty experienced, for some years, and they can more realistic confrontate the quality and image of schools. It could be also because these students attend the faculty only once in a week and they do not know all imperfections as well as full-time students that are at school almost every day.

The items of boarding and dinners were positively and almost identically evaluated by full-time students $(3,36 ; 3,29)$. The group of extramural study evaluated these items negatively $(2,78 ; 2,72)$. Dissatisfaction with boarding quality and feeding hours of dinners by extramural students is quite puzzled because mostly full-time students use the canteen.

Surprising is mainly dissatisfaction with dinner feeding hours, from 11.00 a.m. to 3 p.m., which is quite long range for dinner, I think. Students can choose from five different meals from the dinner menu. I presume the dissatisfaction of extramural students was because the canteen has been closed at the time of their presence at school - on Saturdays.

The indicator - study literature - both groups evaluated negatively, however the rate of negativity is higher at full-time students $(2,4)$ than at extramural students $(2,89)$.

The scale about study timetable - no target group evaluated positively. Full-time students evaluated this indicator negatively $(2,34)$ and extramural students did not choose any side of satisfaction $(3,0)$. Faculty study-timetablemakers are responsible for the quality of timetables that must take into account capacity possibilities of rooms for education. The university has the only auditorium, which has a certain capacity and it is for students of all faculties of the university. The university is looking for other capacity in cooperation with other secondary schools, vocational schools that can hire some rooms for educational purposes. Breaking point of the problem will be after reconstruction of new rooms for FM PU and there should be a new - spatially and technically higher-level auditorium.

The item Practice - both groups evaluated this indicator positively, however the rate of satisfaction is higher at full-time students $(3,42)$ than at extramural students $(3,15)$.

The indicator - preliminary evaluation - we can polemize about the rate of dissatisfaction at extramural students, which limits to neutrality - to three (2.98). Unambiguous rate of satisfaction expressed full-time students that rate of satisfaction approached the value of 3.2. 
Figure No 2. Communications policy

\begin{tabular}{|l|c|c|}
\hline \multicolumn{1}{|c|}{ Study form } & yes & no \\
\hline \multirow{2}{*}{ Full-time students } & 98 & 102 \\
\cline { 2 - 3 } & $49,00 \%$ & $51,00 \%$ \\
\hline \multirow{2}{*}{ Extramural students } & 57 & 93 \\
\cline { 2 - 3 } & $38,00 \%$ & $62,00 \%$ \\
\hline
\end{tabular}

$X^{2}=4,20 ; r=0,04$

Figure No 3. Competitive advantage

\begin{tabular}{|l|c|c|}
\hline \multicolumn{1}{|c|}{ Study form } & yes & no \\
\hline \multirow{2}{*}{ Full-time students } & 127 & 73 \\
\cline { 2 - 3 } & $63,50 \%$ & $36,50 \%$ \\
\hline \multirow{2}{*}{ Extramural students } & 69 & 81 \\
\cline { 2 - 3 } & $46,00 \%$ & $54,00 \%$ \\
\hline
\end{tabular}

$X^{2}=10,65 ; r=0,001$

Between study form and evaluation of communicative policy improving awareness of employees, students, study candidates as a result of university marketing as public non-profitable organizations exist statistically important connection $(0.006<0.05)$. Students of extramural study more inclined to non-positive answer (62\%) than students of full-time study (51\%). It follows extramural students can better imagine under the idea of the university marketing - communicative policy improving awareness of employees, students, study candidates and activities of advertisement type.

Between study form and evaluation of institution attractiveness and approaching of long-term competitive advantage of the university, as a result of the university marketing as public non-profitable organizations, exists statistically important connection $(0.001<0.05)$.

Students of full-time study more inclined to positive answer $(64 \%)$ than students of extramural study (51\%). It follows full-time students imagine more under the idea of the university marketing - improving of attractiveness of the institution and approaching of long-term competitive advantage of the university.

\section{Internal Marketing Approach}

Among marketing communications aims was also classified approaching the highest number of positive attitude changes to the university from the side of present students and pedagogical and non-pedagogical employees, identifying with university aims, creating good atmosphere and improving of working conditions of employees. 
It is not easy to approach these aims, especially, if it is as big institution as the university is. A company culture has to be created in the beginning and improved its attributes have to be improved all the time.

One of problematic sides of the university dropped communication in all directions - from rectorate to faculties, among faculties and into the framework of faculties. It is the matter of all students and employees as well.

New technologies make much easier these processes that should be used at school positively. The fastest and the most effective form of communication are Internet and electronic mail. There must be a precondition all participants have a computer with suitable equipment there. Redone web page of the university offers not only basic information about the university and its study programmes but it is also in effect all kinds of information for variety of groups into the framework of the university.

Organizing variety of social, cultural, sport events separately for the employees and their families can support creating of kindly climate.

For the same purpose can be prepared above-mentioned events, into the framework of organized public relations activities, with a wider purpose but they can include also this target group.

Even the school has not had any self-contained united marketing and communicative strategy and yet it activated also in the field of PR somehow - some seminars were held, conferences with international participation, the school has published its own magazine, it has joined to variety including international projects and it has published informative materials from time to time. These activities were not coordinated and they were not put into the practice to approach certain set up aims.

Therefore we can place a marketing department into the organizational structure in the level of rectorate or at least to reserve a man - marketing expert. This department (marketing expert) would be in charge of creating a school strategy, planning, public relations and coordination of all activities, research activities, etc,

Inquiries are very important for a university (satisfaction of students, teachers, etc., their demands, needs, demands and needs of labour market, etc.) that need to be repeat in regular intervals (if possible more times in a year) and to compare the results.

Another possibility is to use services of specialized marketing companies, Public relations agencies, consulting companies that could be in charge of activities as follows: mapping of needs, preferences, communication with media, lobbying, crisis management, advisory, organization of PR events, etc. Engaging of qualified agency does not bring only services but also new, non-involved outer view, new ideas for aims, strategy and other possibilities. 


\section{Literature}

Bobáková V., Hečková J., The Impact of the Transformation Process on the Industry of the Slovak Republic, In: Restrukturyzacja w okresie transformacji gospodarski, instrumenty przebieg - efecty, Borowiecki R., Jaki A. (ed.), Akademia Ekonomiczna w Krakowie - TNOiK, Kraków - Warszawa 2005.

Butoracová-Šindleryová I., Current Trends and Challenges of Marketing Research, In: Recenzovaný sborník abstraktú z konf. studentú doktorského stud. programu Mezinárodní Bat'ova Doktorandská konference: TISK SPRINT, Zlín 2007.

Chaston I., Managing for Marketing Excellence, McGraw-Hill Book Company Limited, London 1990.

Ďad’o J., Význam regionálnych rozvojových programov, Zborník z medzinárodnej konferencie „Ekonomika podnikov a regiónov - 1997“, Bardejovské Kúpele, PHF Košice EU Bratislava, 1997.

Kotler P., Armstrong G., Marketing, SPN Bratislava 1992.

Kotulič R., Adamišin P., Perspektívy In-Store komunikácie na prelome milénia, In: Marketingová panoráma $3 / 2003$.

Kotulič R., Trends in the Use of the Financial Tools Provided by the EU for the Non-profit Sector Projects, In: Zborník z medzinárodného vedeckého seminára : „Podnikanie a inovácie podnikatel'ských aktivít“, Vyd. Michala Vaška, Prešov 2006.

Mrvová K., Matušíková D., Importance of customer relationship management in tourism industry, In: International Scientific Conference CRM 2006. 1st edition., Press Center of University of Pardubice, Pardubice 2006.

Rákoš, J., Butorac, D.: CRM as an integrated part of the information system.

In: CRM 2006. Customer relationship management '06 [elektronický zdroj]: the international scientific conference; proceedings of the conference. - Pardubice: University of Pardubice, 2006.

Širá E., Manažment znalostí a znalostní pracouníci, In: Zborník z medzinárodnej Bat’ovej doktorandskej konferencie, 12.4.2007, Zlín, CR.

Sojka L., Nástup globalizácie a znalostnej ekonomiky v oblasti vzdelávania, Marketing školy v praxi č 4/ 2007. IURA EDITION, Banská Bystrica.

www.marketinged.com/library/newsltr/1112mhe.txt

www.marketinged.com/library/newsltr/1209mhe.txt.

\section{Działalność marketingowa uczelni funkcjonująych w regionach rozwijajacych się gospodarczo}

\section{Streszczenie}

Określone podejścia dla marketingu szkót wyższych sa szeroko dyskutowane $w$ ciagu ostatniej dekady. Uczelnie zatożone szczególnie $w$ zacofanych gospodarczo regionach maja specjalnq pozycję, funkcję, możliwości i określone potrzebne dziatalności. Również na rynku stowackim jest wiele powodów stosowania zmodyfikowanych strategii ich funkcjonowania. W artykule przedstawiono wyniki badań gtównych podejść w zarządzaniu marketingowym uczelni stowackich. Próba badawcza obejmowata studentów Wydziatu Zarzqdzania, Uniwersytetu $z$ Prešov. Sprzedaje on celowo zaprojektowanq polityke produktu i komunikacji marketingowej. W końcowej części opracowania zasugerowano szkotom wyższym racjonalna polityke marketingowa. 